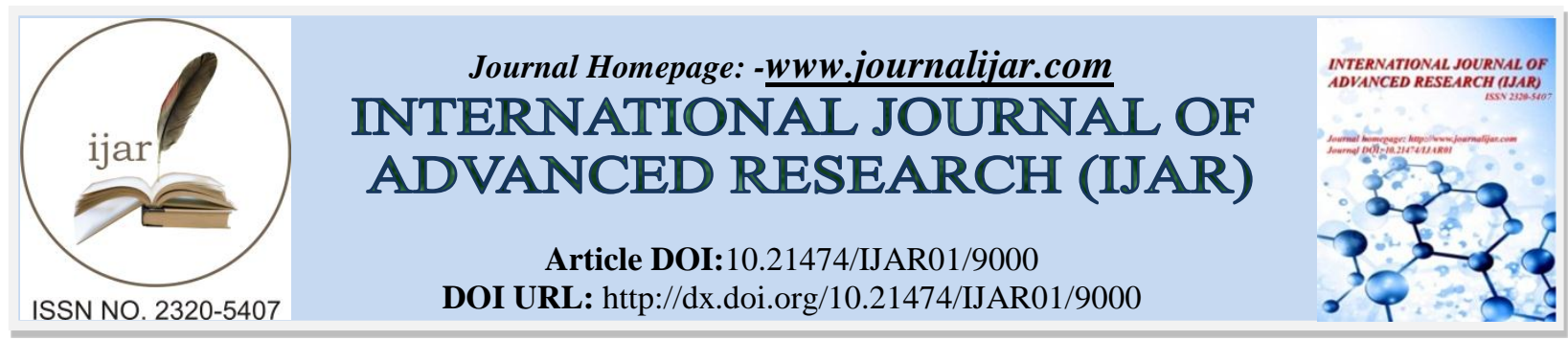

RESEARCH ARTICLE

\title{
COURT INTERPRETATION OF AUDIT EVIDENCE IN THE CASE OF WHITE COLLAR CRIME.
}

\section{Intan Timur ${ }^{1}$, Ratna Ayu Damayanti ${ }^{2}$ and Syamsuddin ${ }^{2}$.}

1. Magister of Accounting, Faculty of Economics and Business, Hasanuddin University, Indonesia.

2. Departement of Accounting, Faculty of Economics and Business,Hasanuddin University, Indonesia.

\section{Manuscript Info}

\section{Manuscript History}

Received: 01 March 2019

Final Accepted: 03 April 2019

Published: May 2019

Key words:-

Court Interpretation, Audit Evidence, White Collar Crime.

\begin{abstract}
This study aims to see how the interpretation of the court (Judges and Public Prosecutors) in seeing the audit evidence presented at the trial of a criminal act. This research is a qualitative research that uses a normative juridical approach. Data is obtained through an interview process and direct observation of the criminal proceedings. The data analysis tool used is a critical discourse analysis developed by Norman Fairclough.

The results of this study indicate that between the Public Prosecutor and the Judge have the same view in assessing the audit evidence of the case of the Makassar Maju Savings and Loan Cooperative. Makassar Maju Savings and Loans Cooperative indicated that the Revolving Fund Management Institution had misappropriated funds through the Audit Report of the State Financial Losses Calculation (LHPKKN) calculated by the South Sulawesi BPKP auditor based on audit evidence collected.
\end{abstract}

Copy Right, IJAR, 2019,. All rights reserved.

\section{Introduction:-}

Audit has an important role in every field both business, government, and economics. In a company the audit role is very important. Without an impossible audit, the company can run as expected. Audit plays an important role in a business entity to reduce information risk between report makers (management) and report users (users). The more complex the condition of a society allows decision makers to obtain information that is unreliable and unreliable (Arens et al, 2003). An auditor has an important role in bridging the interests of parties outside the company such as investors and the interests of the company as a user and provider of financial statements. Company data will be more easily trusted by investors and users of financial statements if they reflect the performance and financial condition of the company obtaining a reasonable statement from the auditor (Majid and Kartini, 2016).

Mulyadi (2002) audit evidence is all information that supports numbers or other information presented in financial statements that can be used by the auditor as a reasonable basis for expressing his opinion. Audit evidence that supports financial statements consists of accounting data and reinforcement information. Accounting data in the form of journals, ledgers, subsidiary books and accounting manuals. While the amplifier information in the form of all documents such as checks, invoices, confirmations and written statements from the parties who know and information obtained by the auditor through information, observation and physical examination.

Corresponding Author:-Intan Timur.

Address:-Magister of Accounting, Faculty of Economics and Business, Hasanuddin University, Indonesia. 
Zakaria and Ahmad (2014) explain that audit evidence influences the reliability and quality of auditor reports. That is, that competent audit evidence can support the auditor's decision on the results of the examination. The interpretation or view between the evidence from the audit side and the evidence according to the legal view is clearly different. If the auditor has completed all the necessary audit evidence, and finds an element of state financial loss, the suspect is considered guilty. But when it arrived at the litigation stage, the Judge was asked not only to see from one piece of evidence, but with 5 pieces of evidence coupled with his conviction as a Judge. This triggered the possibility that in other evidence it showed that the defendant was guilty or innocent. Rifai (2014: 94) explains that a Judge in making a decision must pay attention to all aspects in it, starting from the need for caution, avoiding as little as possible inaccuracies, both formal and material to the existence of technical skills to make it.

Judges in the trial process are domiciled. This position gives the right to regulate the proceedings of the session and take action whenever there is disorder in the session. For the purposes of the decision, the judge has the right and must collect statements from all parties, especially from witnesses and defendants including their legal counsel. The honorable position of the judge is also balanced with heavy responsibility. It is said to be heavy, because it must realize that because of his oath of office so that he is not only responsible to the law, to himself and to the people, but also must be accountable to God Almighty.

Muhammad (2013: 44-45) in his research explained that related to his responsibilities as law enforcement, it was considered important for a judge not only as a skilled officer to improve his ability in the legal technical field but also to reflect the authority that the judge was God's representative. in resolving all disputes it faces.

To settle a case in a trial The judge must see five pieces of evidence and evidence presented in the trial process. This is in accordance with the rules in Article 184 paragraph (1) which states that legal evidence in a criminal court is: witness statements, expert testimony, letters, instructions, and statements of the defendant. For the testimony of expert witnesses, stipulated in Article 186 of the Criminal Procedure Code, what an expert states in the trial. The expert witness referred to in this case was the Auditor who was asked for his testimony regarding the examination carried out against the Makassar Maju saving and loan cooperative.

Satyawan and Khusna (2017), conducting research on disclosure of corruption through audit evidence is evidence according to law. Based on the results of his research found the results that the Report on the Calculation of State Financial Losses is not necessarily believed by the judge because it is one of the tools and not the only evidence used in determining the criminal acts of corruption. The study also revealed that not all audit evidence could be used as legal evidence.

Regarding the discussion of audit evidence, in this study the author's focus is more on how the carrying capacity of the prosecutor's office and the auditor will be used as a basis for disclosing and ensnaring perpetrators of corruption cases at the level of litigation. This is based on the writer's curiosity about the many phenomena of cases that occur in Indonesia. This phenomenon illustrates how many cases of corruption involve actors who have high positions and authority in an organization and even government (Sutherland, 1939).

The aim that the writer wants to achieve from this research is to see how the court's views are related to the audit evidence in the trial of the White-Collar crime case. To achieve the objectives of the study researchers used a discourse analysis approach. In accordance with what was disclosed by Feagin, Orum \& Sjoberg in book A case for the case study which explained that discourse analysis is a multi-perspective research method, namely research that requires analysis from various perspectives rather than focusing on individuals who are objects research only. Researchers also need to pay attention to other aspects such as groups that are relevant to individuals related and have interactions with each other, to be able to provide strength to those who are weaker (powerless) and unable to express opinions (voiceless).

\section{Literature Review \\ Legal realm}

In the legal sphere, evidence, facts, data and information can be grouped into five parts, namely: the type of evidence evidence witnesses, expert statements, letters, instructions and statements of the defendant (Criminal Law Article 184). However, Article 184 of the Criminal Code is not sufficient enough to ensnare some cybercriminals. This is because the evidence relating to the crimes they committed cannot be submitted as legal evidence in court. This is because in Article 184 of this Criminal Code does not contain all forms of evidence contained in the field. 


\section{Accounting domain (audit)}

In the accounting or audit domain, evidence can be grouped into two categories, namely the underlying financial evidence and corroborating financial evidence (konrath, 2001: 114), meaning that audit evidence in the underlying category of financial evidence will be in the form of construction evidence such as journals, ledgers and balance sheets balance. While the corroborating financial evidence is in the form of reinforcement evidence in the form of invoices, documents and other supporting evidence.

\section{A. Definition of Audit Evidence According to Law No. 8 of 1981 concerning Criminal Procedure Law}

Legitimate evidence in criminal procedural law is regulated in the provisions of Article 184 paragraph (1) of the Criminal Procedure Code, among others: witness statements, expert statements, letters, instructions and statements of the defendant. Evidence is considered competent if the evidence contains elements such as valid, reliable, and consistent with the facts (Pacini et al, 2016). Evidence is said to be relevant if the evidence has a logical relationship and significance for the findings in the examination in question (Beisland et al, 2015). Audit evidence can not always be directly used as a means of proof in a criminal act of corruption, this is because audit evidence is part of information that cannot be separated from legal evidence, in accordance with what has been stipulated in Article 184 paragraph (1) of the Criminal Code.

Expert information according to Article 186 that what is meant by expert information is what an expert declares in a court session. In Article 184 paragraph (1) it is stated that expert information is one of the legitimate evidences, parallel to several other evidences. The definition of expert information according to Article 1 point 28 of the Criminal Procedure Code states that "expert information is information provided by a person who has special expertise about the things needed to make light of a criminal case for the purpose of examination". In some cases not all criminal cases require expert information as evidence. However, if in a criminal case an expert statement is filed, then it can be said that the expert statement is an evidence needed and considered important for the settlement of the case (Wulur, 2017).

\section{B. Proof in the Criminal Procedure Code}

Proving that according to the large Indonesian dictionary is a process of deed, the way to prove a business determines the correctness of the defendant's trial in the court. In the trial of criminal cases, a criminal judge in seeking material truth, the event must be beyond reasonable doubt (Sofyan, 2013).

The proof system is a system that contains what evidence can be used to prove, how the evidence can be used as well as the value of the strength of the evidence to the standard or criteria that become a measure in drawing conclusions about the proof of something (object ) proven. The proof system is also a roundness or the whole of various provisions concerning evidentiary activities which are interconnected with one another that are inseparable and become a unified whole (Chazawi, 2008: 24).

\section{Difference between Evidence}

The evidence is regulated in Article 184 paragraph (1) of the Criminal Procedure Code which states that valid evidence is: witness testimony, expert information, letters, instructions and statements of the defendant. In the system of proof of criminal procedure only evidence is considered valid according to the law that can be used for verification (Prodjohamidjojo, 1983: 19). Evidence based on Article 39 Paragraph (1) of the Criminal Procedure Code states that regarding what can be confiscated include: Objects or bills of suspects or defendants which are allegedly obtained in whole or in part from criminal acts or as a result of criminal offenses, objects that have been used directly to commit a crime or to prepare it, objects that are used to obstruct investigations of criminal acts, objects specifically made or intended to carry out criminal acts, other objects that have a direct relationship with the crime committed.

According to Prodjohamidjojo, evidence is used for the purpose of crime. While Hasibuan (1990) argues that evidence is goods used by the defendant to carry out an offense or the result of an offense, which is confiscated by the investigator to be used as evidence in court. Based on the explanation above, it can be seen that the position of the evidence in the court proceedings is to strengthen the position of legal evidence, besides that the evidence can also be used to strengthen the judge's belief in the accused charges. 


\section{Research Methods:-}

This study uses a qualitative approach that aims to find out how the court interpreted the audit evidence presented in the trial in the case of White-Collar Crime fraud. Qualitative research is research that aims to describe and analyze phenomena, events, social activities, beliefs, perceptions, thoughts and individuals and groups (Sukmadinata, 2011: $60)$.

The location of the case study in this study was carried out in two places, namely at the South Sulawesi High Prosecutor's Office located at Jalan Jenderal Urip Sumoharjo KM.4 No. 244 Makassar and the Makassar Class IA District Court located on Jl. R.A Kartini No 18/23 Makassar. The time used for this study is 4 months, which is from December 2018 to March 2019. The key subject of this research object was participants who came from employees of the South Sulawesi Prosecutor's Office who served as Functional Investigators/Prosecutors who specialized in handling corruption cases or criminal acts of corruption. Spradley (1990) revealed that informants must have several criteria that need to be considered, one of which is the subject is still fully and actively engaged in the environment and activities that are targeted or researched.

In this study the authors used data analysis techniques using critical discourse analysis. Critical discourse analysis (critical discourse analysis) is a term used to describe various research approaches that focus on language use. There are several types of discourse analysis such as conversation analysis, discursive psychology, critical discourse analysis and foucault discourse analysis. Each of these analyzes has its own assumptions. Emphasis and methods but overlapping interests are key in the way that meaning is built in communication.

According to Fairclough (1989) every discourse that appears in the form of text, conversation, is not seen as something scientific, reasonable and neutral but is a form of struggle for power struggle. Furthermore, according to Fairclogh (1995) explained that the text is considered as a domain of representation and significance of the world and experience and is open to various interpretations.

\section{Results And Discussions:-}

Use of Text in the Case of the Makassar Savings and Loan Cooperative going forward. In the use of text, each text analysis together has three functions, namely representation, relations and identity. The use of this text is done so that it can be the theme raised by the Public Prosecutor who describes the Prosecutor's view of the Case involving the Makassar KSP Forward. the view of the Public Prosecutor can be seen through the use of words and sentence structure used in the speech at the trial.

"Chairman and Treasurer of the Makassar Savings and Loan Cooperative Advances jointly or acts individually as a party who acts against the law, enriches himself or a corporation that has harmed the country's finances" In the case that ensnared the Makassar Forward Forward, the intended evidence could explain all the actions taken by the defendant including: 1 (One) duplicate Original Financial Report period 31 December 2011 and Independent Auditor's report, 1 (One) duplicate Original period Financial Report December 31, 2012 and Independent Auditor's report 1 (one) duplicate, 1 (one) original bundle of Makassar Advanced KSP credit proposal 3 (three) original sheets Definitive List of Micro, Small Business Recipients of Ministry of Micro, Small and Medium Enterprises Funds through the Makassar Advanced Cooperation dated 11 May 20131 (one) original bundle of Makassar KSP Loan / Financing agreement Forward Number: 141 Notary H. Warman.

after the disbursement of the revolving aid fund was channeled to the advanced Makassar savings and loan cooperative, it turned out that the funds were not used in accordance with the allocation. Instead it is used as follows: A total of Rp1,006,480.00.00 deposited at Rural Bank Dana Niaga Mandiri for collateral deposits to LPDBMinistry of Micro, Small and Medium Enterprises, IDR 600,000,000.00 is used to take over customers of Rural Bank Dana Niaga Mandiri (the one who disbursed was Nurulhuda, one of the employees of Rural Bank Dana Niaga Mandiri Mandiri), A total of IDR 294,000,000. is used to takeover customers of Rural Bank Dana Niaga Mandiri Mandiri (the one who made the withdrawal is sahrul, one of the Officeboys at Rural Banks Dana Niaga Mandiri) IDR 165,500,000.00 is used to buy four-wheeled vehicles purchased from Andi Baso Amirullah (Commissioner of Rural Bank Dana Niaga Mandiri), IDR 480,000,000.00 is an loan from Anwar Ishak, A total of IDR 1,006,480.00.00 deposited at Rural Bank Dana Niaga Mandiri for collateral deposits to Ministry of Micro, Small and Medium Enterprises, As much as IDR 600,000,000.00 is used to take over customers of Rural Bank Dana Niaga Mandiri (the one who disbursed was Nurulhuda, one of the employees of PT. BPR Dana Niaga Mandiri), As much as IDR 294,000,000.00 is used to takeover customers of Rural Bank Dana Niaga Mandiri (the one who 
made the withdrawal is sahrul, one of the Officeboys at PT. BPR Dana Niaga Mandiri), IDR 155,500,000.00 was used to buy four-wheeled vehicles purchased from Andi Baso Amirullah (Commissioner of Rural Bank Dana Niaga Mandiri), IDR 480,000,000.00 is an loan from Anwar Ishak

Based on the discussion related to the results of the Public Prosecutor's interpretation of the evidence presented in the trial, the researcher can draw a result that based on the results of the text analysis related to the interpretation of the Public Prosecutor:

1. Based on the relationship between the testimonies that the Public Prosecutor assessed the audit evidence and other evidence which indicates the existence of redflag that the defendant committed an unlawful act was strong.

2. The Public Prosecutor in making a claim after the inspection process is complete. These demands are made based on witness statements, expert statements, letters, instructions and statements of the defendant.

3. In terms of the social context, it can be seen that the Public Prosecutor in presenting evidence in the trial is considered important to determine whether there is an illegal act. This shows that the position of a Prosecutor as a law enforcement officer must uphold justice. Therefore, as a Prosecutor it is required to prove the charges through the evidence presented at the trial.

\section{Conclusions and Recommendation:-}

Based on the results of the analysis of the interpretation between the Public Prosecutor and the Judge, it was found that it turned out that in interpreting the audit evidence between judges and the Public Prosecutor had the same interpretation. This can be seen from the responses of the Judges and Prosecutors regarding the crimes committed by the two defendants. Judges and prosecutors assess that the use of the flow of funds used by Savings and Loans Cooperatives using state funds violates the law. In addition, the existence of self-enrichment and corporate elements was also assessed by the Public Prosecutor and Judge during the trial that the Makassar Advanced Savings and Loan Cooperative was involved in transactions with the Dana Niaga Mandiri Credit Bank several times. In addition, the most prominent thing is that funds are not really channeled to the community.

The Public Prosecutor believes that the defendant committed a criminal offense based on the results of the audit conducted by referring to the state financial loss arising from the defendant's actions. State financial losses are calculated based on the results of an examination of the financial statements of the Makassar Maju Savings and Loans Cooperative which shows the flow of funds from the KSP Forwarding Makassar.

Based on the results of research conducted on the crime of the Makassar Maju Savings and Loan Cooperative case, it was found the fact that the court's interpretation of audit evidence played an important role in proving the crime. This is because through the audit results it can be seen that the transaction flow from the Makassar Forward and Savings Cooperative is used for what purpose. In addition to the results of the audit, expert witnesses presented by the Public Prosecutor in the trial can provide clearer information regarding the results of the audit conducted. This information is related to the return of state money that was corrupted by the perpetrator. So that based on the expert's information it can be enlightened and input to the Judge as law enforcer to be able to assess whether the defendant is guilty or not.

For further research, it is intended to expand the object of research not only in cases handled by the High Prosecutor's Office. But (the Corruption Eradication Commission) and the Police are law enforcement agencies that also handle special criminal cases. By expanding the object of research the researcher can see how the differences between each law enforcement agency in handling a criminal case and how the process of gathering evidence is carried out by the investigators of each of these institutions.

In addition, it is recommended for further research to increase the number of cases to be investigated in order to be able to compare the differences in fraud schemes that occur and how the law enforcers interpret the audit evidence submitted in court.

\section{References:-}

1. Adhami, Chazawi, 2008. Hukum Pembuktian Tindak Pidana Korupsi, Bandung :

Alumni.

2. Arens et al. 2003. Ninth Edition. Auditing and Assurance Service-An Integrated Jersey:Prentice Hall

3. Hasibuan, Ansori dan Ruben. 1990. Hukum Acara Pidana. Bandung 
4. Kitab Undang-Undang Hukum Pidana (Criminal Law Book)

5. Kitab Undang-undang Hukum Acara Perdata (KUHAP)

6. Majid, Jamaluddin dan Kartini. 2016. Potret Hubungan auditor-Klien: Sebuah Studi Interaksi simbolikdiKantor Akuntan Publik. Akuntansi Peradaban : Vol. II No. 1 Juli 2016

7. Mulyadi. 2002. Auditing. Edisi ke-6, cetakan pertama. Jakarta:Salemba Empat.

8. Satyawan, Made Dudy, Khusna, 2017. Mengungkap Korupsi Melalui Bukti Audit Menjadi Bukti Menurut Hukum. Jurnal Akuntansi Multiparadigma, Volume 8, Nomor 1,Hlm 1833-1999 Setiabudhi, Rai dan Swardhana, Made. 2015. Sanksi Hukum terhadap Notaris yang Melanggar Kewajiban dan Larangan Undangundang Jabatan Notaris.Jurnal Ilmiah Prodi Magister Kenotariatan 2016-2017

9. Sutherland edwin, dan Cressey, Donald. Principles of criminology. Eleventh Edition, Rowman \& Litlefield Inc. 1992

10. Sofyan, Andi, 2013. Hukum Acara Pidana Suatu Pengantar. Yogyakarta : Rangkang Education,241

11. Sutherland, E. H., 1940, "White Collar Criminality", American Sociological Review, Vol. 5,No.1:20.

12. Wulur, Nixon. 2017. Keterangan Ahli dan Pengaruhnya Terhadap Putusan Hakim. Lex Crimen Vol. VI/No.2/Maret-April/2017

13. Zakaria, M. Abulgasem dan Nassr Saleh Mohamad Ahmad.(2014). The Role of Audit Evidence Source in Enhancing the Quality and Reliability of Libyan Auditor's Report. Review Of Integrative Bussiness and Economic Research, 3(1), 1-12.

14. Fairclough, N. 1995a. Critical Discourse Analysis: The Critical Study of Language.London: Longman. 